\title{
RETENTION OF PHOSPHATE BY PEAT SAMPLES
}

\author{
ARMi KaILA \\ University of Helsinki, Department of Agricultural Chemistry
}

Received June 17, 1959

Since Way in 1850 (ref. 15) demonstrated that soils are able to retain soluble phosphate, the problem of the sorption of phosphate by soils and soil constituents has been dealt by a great number of scientific papers. Generally, these works confirm the early results. They give, however, a somewhat confusing picture regarding the reactions involved.

Most of the studies have been made on mineral soils. Among the few works concerning peat soils the papers by Doughty $(1,2)$ and Kasakow $(6)$ may be mentioned. These authors conclude that precipitation and physical adsorption are both functioning in the removal of phosphate from solution by peat samples. Doughty states that in the material studied the formation of iron, aluminum and calcium phosphates will account for the fixation of phosphorus under field conditions. According to KASAKOw, the maximum retention of phosphate by peat occurs at

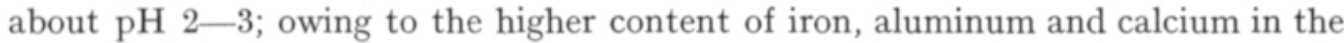
fen peat, the fixation of phosphate by this group is higher than that by the bog peats. McCool (9) noted that the capacity of peat and muck soils to take up phosphorus increased with the mineral content and the degree of decomposition. VERHOEven (14) maintains that the retention of phosphate by irreversibly shrinking peat soils primarily depends on the mobile iron content of the soils. LARSEN (8) found a positive correlation between the sesquioxide content of organic soils and their phosphate fixing capacity.

Obviously, the retention of phosphate by peat soils may be connected with several factors. In the present paper an attempt is made to study the capacity of Finnish virgin peat soils to retain phosphate and the factors on which this capacity depends.

There is no generally accepted way to determine the phosphate-sorption capacity of a soil. It is a quantity which varies with the ratio of soil to phosphate solution and with the phosphorus concentration of the solution. Other ions present also exert their effect, likewise the acidity, temperature, and time of connection. 
Therefore, one is compelled to choose a more or less conventional method which gives values that, at least, are correlated with the phosphate fixing capacity of the soil. Russel and Prescott (13) already found that the relationship between the amount of phosphate sorbed and the corresponding equilibrium concentration of phosphate in experiments generally comply with the Freundlich adsorption isotherm. Recently Olsen and Watanabe (10) and Rennie and McKercher (12) have emphasized the applicability of the Langmuir isotherm to the estimation of phosphate retention by soils.

In this study the coefficient $\mathrm{k}$ in the Freundlich adsorption equation $\mathrm{y}=\mathrm{k} \times \mathrm{c}^{\mathrm{n}}$ was taken to characterize the retention of phosphate by the peat samples $(\mathrm{y}=$ the amount of $\mathrm{P}$ adsorbed, $\mathrm{mg} / \mathrm{kg}$ of soil, $\mathrm{c}=$ the equilibrium concentration of phosphorus in the solution $\mathrm{mg} / \mathrm{l}, \mathrm{n}=\mathrm{a}$ constant). According to Russell and PrescotT (13) $\mathrm{k}$ wrepresents the tenacity with which the soil keeps its phosphate or the reluctance with which the soil parts with its phosphate under the conditions of the experiment». The factors the effect of which on the value of $\mathrm{k}$ was studied in the present work were the degree of humification and the acidity of the peat, the sampling depth, the amount of extractable calcium, and the amounts of iron and aluminum soluble in diluted hydrochloric acid.

\section{Material and methods}

The material of the present study consisted of 134 peat samples collected from different layers of virgin peat lands.

The samples were air-dried and ground in a Wiley mill. The methods used for the determination of the degree of decomposition $(\mathrm{H})$, the weight of volume, $\mathrm{pH}$, and the content of extractable calcium are described in previous papers $(4,5)$.

The nexchangeable" phosphorus was extracted by an alkali solution $0.1 \mathrm{~N}$ with respect to potassium hydroxide and potassium carbonate. The ratio of soil to solution was $1: 100$, and the shaking time was $2+4$ hours in two consecutive days. The inorganic phosphorus in the solution was determined after the precipitation of the organic matter by sulphuric acid.

The coefficient $\mathrm{k}$ in the Freundlich adsorption equation was calculated on the basis of data for removal of phosphorus by 5 grams of peat from $100 \mathrm{ml}$ of $\mathrm{KH}_{2} \mathrm{PO}_{4^{-}}$ solution containing phosphorus $15.5 \mathrm{mg} / \mathrm{l}$ and $155.0 \mathrm{mg} / \mathrm{l}$, respectively. The suspensions were heated on a boiling water-bath for two hours in two consecutive days. The values of "exchangeable" phosphorus were used in the calculations to represent the native sorbed phosphate.

Iron and aluminum were extracted from $2 \mathrm{~g}$-samples with $100 \mathrm{ml}$ of $0.1 \mathrm{~N}$ $\mathrm{HCl}$ by shaking for one hour. The iron dissolved was determined by the method of KUNin (7). The aluminum content of the extract was estimated by the Aluminon method in which the disturbing effect of iron was eliminated by hydroxylamine hydrochloride. 
Table 1. Analyses of peat samples.

\begin{tabular}{|c|c|c|c|c|c|c|c|c|}
\hline $\mathrm{G}_{\mathrm{s}}$ & & & & Volume & Exchange- & & Extract- & $0.1 \mathrm{~N} \mathrm{HCl}$-soluble \\
\hline & dm & $\mathrm{H}$ & pn & weight & ppm & K & ppm & Fe ppm Al ppm \\
\hline
\end{tabular}

\section{Sphagnum peat}

$\begin{array}{rrrrrrrrrrr} & 65 & 0-2 & 1 & 3.7 & 0.05 & 68 & 0 & 1800 & 110 & 120 \\ \mathrm{~K} & 31 & 0-2 & 1 & 4.2 & 0.08 & 58 & 0 & 4100 & 170 & 170 \\ \mathrm{~K} & 32 & 4-6 & 1 & 4.4 & 0.08 & 28 & 0 & 4700 & 280 & 270 \\ \mathrm{~K} & 21 & 0-2 & 1 & 4.3 & 0.09 & 71 & 0 & 6200 & 50 & 180 \\ \mathrm{~K} & 34 & 0-2 & 1 & 4.2 & 0.09 & 72 & 112 & 3400 & 2840 & 3250 \\ \mathrm{~A} & 4 & 3-5 & 1 & 4.7 & 0.10 & 15 & 0 & 2800 & 110 & 180 \\ \mathrm{~K} & 37 & 0-2 & 1 & 4.5 & 0.11 & 96 & 0 & 4900 & 490 & 470 \\ \mathrm{~K} & 6 & 1-2 & 1 & 4.5 & 0.11 & 144 & 8 & 7000 & 1220 & 1700 \\ \mathrm{~A} & 27 & 0-2 & 1 & 4.5 & 0.12 & 31 & 209 & 2000 & 210 & 3600 \\ & 36 & 0-2 & 1 & 4.0 & 0.12 & 70 & 36 & 2000 & 610 & 2300 \\ \mathrm{~A} & 37 & 0-2 & 1 & 4.4 & 0.28 & 53 & 40 & 3200 & 2000 & 1250 \\ \mathrm{~A} & 31 & 0-2 & 1 & 3.9 & 0.29 & 64 & 0 & 2100 & 410 & 1050 \\ & 66 & 2-5 & 1 & 3.6 & 0.09 & 34 & 0 & - & 280 & 230 \\ \mathrm{~K} & 22 & 2-4 & 2 & 5.0 & 0.14 & 72 & 0 & 10600 & 140 & 100 \\ \mathrm{~K} & 7 & 2-3 & 2 & 4.6 & 0.17 & 154 & 126 & 6800 & 1440 & 2730 \\ \mathrm{~A} & 5 & 5-7 & 3 & 4.9 & 0.23 & 19 & 0 & 3500 & 170 & 440 \\ \mathrm{~A} & 1 & 2-3 & 3 & 3.7 & 0.29 & 35 & 0 & 3200 & 300 & 970 \\ \mathrm{~A} & 32 & 3-5 & 3 & 4.0 & 0.34 & 35 & 3 & 1500 & 140 & 1150 \\ \mathrm{~A} & 6 & 12-14 & 4 & 4.7 & 0.21 & 19 & 0 & 7100 & 140 & 440 \\ & 105 & 2-4 & 4 & 4.4 & 0.20 & 27 & 0 & 5800 & 80 & 110 \\ \mathrm{~A} & 2 & 3-4 & 5 & 3.8 & 0.49 & 40 & 0 & 3600 & 440 & 850 \\ \mathrm{~A} & 3 & 7-10 & 7 & 4.4 & 0.38 & 36 & 137 & 5600 & 2160 & 3130 \\ & & & & & & & & & \end{array}$

Carex-Sphagnum peat

$\begin{array}{rrrrrrrrrrr} & 69 & 0-3 & 2 & 4.2 & 0.09 & 135 & 0 & 2300 & 610 & 930 \\ \mathrm{~K} & 38 & 2-4 & 2 & 4.6 & 0.23 & 95 & 0 & 4300 & 610 & 560 \\ & 107 & 1-3 & 3 & 4.4 & 0.16 & 83 & 51 & 2000 & 560 & 1820 \\ & 28 & 4-6 & 3 & 4.2 & 0.23 & 27 & 9 & 2100 & 2110 & 950 \\ & 37 & 0-3 & 3 & 4.7 & 0.33 & 44 & 22 & 2800 & 220 & 1910 \\ \mathrm{~A} & 52 & 1-3 & 3 & 3.8 & 0.33 & 54 & 0 & 1530 & 860 & 550 \\ \mathrm{~K} & 39 & 4-6 & 4 & 4.6 & 0.25 & 53 & 0 & 3500 & 380 & 1100 \\ \mathrm{~A} & 28 & 5-7 & 4 & 4.3 & 0.30 & 19 & 123 & 1600 & 250 & 3270 \\ & 70 & 3-5 & 4 & 4.4 & 0.25 & 103 & 22 & 1730 & 460 & 2230 \\ & 34 & 0-3 & 4 & 4.5 & 0.34 & 60 & 399 & 1300 & 2720 & 3650 \\ & 35 & 0-3 & 4 & 4.5 & 0.38 & 75 & 318 & 2600 & 2670 & 2550 \\ \mathrm{~K} & 8 & 3-4 & 5 & 4.6 & 0.39 & 96 & 299 & 3900 & 1060 & 4500 \\ \mathrm{~K} & 33 & 6-8 & 5 & 4.5 & 0.25 & 62 & 0 & 4400 & 550 & 690 \\ & 29 & 15-20 & 5 & 5.1 & 0.33 & 18 & 123 & 4400 & 5670 & 2450 \\ \mathrm{~A} & 29 & 8-10 & 5 & 4.1 & 0.35 & 27 & 50 & 1800 & 260 & 2150 \\ & 106 & 2-4 & 6 & 4.7 & 0.26 & 82 & 36 & 5600 & 210 & 1340 \\ & 71 & 7-10 & 6 & 4.3 & 0.36 & 54 & 139 & 1180 & 260 & 3350 \\ \mathrm{~K} & 42 & 2-4 & 7 & 3.9 & 0.39 & 71 & 66 & 3000 & 260 & 2140 \\ \mathrm{~A} & 46 & 4-6 & 7 & 4.1 & 0.49 & 52 & 78 & 2200 & 280 & 2100\end{array}$


Sample Depth $\begin{gathered}\text { Volume Exchange- } \\ \text { able P }\end{gathered}$

Extract-

$0.1 \mathrm{~N} \mathrm{HCl}$-soluble

pH weight ppm

able $\mathrm{Ca}$

Fe ppm $\quad \mathrm{Al}$ ppm

Sphagnum-Carex peat

\begin{tabular}{|c|c|c|c|c|c|c|c|c|c|}
\hline 28 & $0-2$ & 1 & 4.5 & 0.20 & 115 & 26 & 4500 & 2080 & 1300 \\
\hline 19 & $1-3$ & 2 & 5.0 & 0.25 & 46 & 13 & 6000 & 830 & 740 \\
\hline 12 & $3-5$ & 2 & 4.8 & 0.25 & 44 & 16 & 4600 & 1500 & 1250 \\
\hline 23 & $1-3$ & 2 & 4.7 & 0.38 & 99 & 63 & 4400 & 2170 & 1250 \\
\hline 59 & $0-2$ & 3 & 3.6 & 0.23 & 98 & 106 & 1600 & 1220 & 1800 \\
\hline 12 & $0-1$ & 3 & 4.4 & 0.27 & 101 & 240 & 5100 & 1000 & 2650 \\
\hline 14 & $1-3$ & 3 & 4.3 & 0.30 & 31 & 5 & 4800 & 1890 & 900 \\
\hline 53 & $1-3$ & 3 & 4.2 & 0.42 & 31 & 43 & 1100 & 220 & 1800 \\
\hline 47 & $2-4$ & 3 & 4.6 & 0.23 & 62 & 519 & 2400 & 6120 & 3900 \\
\hline 11 & $0-2$ & 3 & 4.9 & 0.26 & 46 & 18 & 2400 & 830 & 820 \\
\hline 16 & $6-8$ & 3 & 4.5 & 0.30 & 28 & 57 & 1800 & 120 & 2200 \\
\hline 35 & $0-4$ & 3 & 5.5 & 0.31 & 40 & 0 & 13200 & 40 & 80 \\
\hline 18 & $0-2$ & 3 & 5.5 & 0.27 & 67 & 74 & 3300 & 1000 & 1600 \\
\hline 6 & $1-3$ & 4 & 4.3 & 0.21 & 74 & 303 & 2160 & 3780 & 2200 \\
\hline 24 & $6-8$ & 4 & 5.1 & 0.35 & 25 & 0 & 6600 & 750 & 330 \\
\hline 49 & $1-3$ & 4 & 4.3 & 0.34 & 95 & 30 & 2700 & 2840 & 1700 \\
\hline 89 & $0-2$ & 4 & 4.5 & 0.22 & 155 & 0 & - & 2280 & 1050 \\
\hline 33 & $0-3$ & 4 & 4.7 & 0.30 & 100 & 0 & 2700 & 1330 & 680 \\
\hline 20 & $4-6$ & 4 & 4.2 & 0.30 & 31 & 0 & 2900 & 390 & 560 \\
\hline 2 & $1-3$ & 4 & 4.1 & 0.33 & 26 & 145 & 1840 & 430 & 3100 \\
\hline 15 & $2-4$ & 4 & 4.3 & 0.34 & 52 & 19 & 2100 & 1000 & 1540 \\
\hline 7 & $4-6$ & 4 & 4.3 & 0.33 & 69 & 272 & 2360 & 4170 & 2650 \\
\hline 8 & $8-12$ & 5 & 4.4 & 0.30 & 71 & 329 & 2500 & 4950 & 3450 \\
\hline 33 & $8-10$ & 5 & 4.1 & 0.30 & 25 & 20 & 1300 & 100 & 1910 \\
\hline 60 & $3-9$ & 5 & 3.5 & 0.32 & 53 & 7 & 1700 & 1000 & 850 \\
\hline 35 & $4-6$ & 5 & 4.9 & 0.34 & 99 & 170 & 3400 & 1250 & 2830 \\
\hline 23 & $4-6$ & 5 & 5.0 & 0.32 & 42 & 0 & 7900 & 420 & 210 \\
\hline 3 & $\begin{array}{ll}4-6\end{array}$ & 6 & 4.0 & 0.36 & 22 & 250 & 790 & 680 & 4300 \\
\hline 59 & $0-5$ & 6 & 5.3 & 0.45 & 30 & 83 & 3000 & 780 & 1980 \\
\hline 61 & $10-13$ & 7 & 4.5 & 0.40 & 52 & 268 & 1900 & 3490 & 3550 \\
\hline 76 & $60-62$ & 9 & 4.8 & 0.71 & 60 & 71 & 4400 & 1120 & 2300 \\
\hline
\end{tabular}

Carex-peat

$\begin{array}{rrrrrrrrrrr}\mathrm{K} & 29 & 5-7 & 2 & 4.6 & 0.20 & 94 & 91 & 3700 & 2060 & 1500 \\ \mathrm{~B} & 10 & 1-3 & 3 & 4.3 & 0.20 & 26 & 68 & 1570 & 1780 & 1800 \\ & 24 & 1-3 & 3 & 5.0 & 0.22 & 33 & 30 & 6470 & 260 & 1270 \\ \mathrm{~A} & 40 & 0-2 & 3 & 4.7 & 0.30 & 39 & 30 & 3550 & 2610 & 1000 \\ \mathrm{~A} & 41 & 3-5 & 3 & 4.8 & 0.25 & 18 & 13 & 2400 & 2330 & 900 \\ \mathrm{~A} & 8 & 0-3 & 3 & 4.7 & 0.32 & 36 & 126 & 3970 & 6340 & 2350 \\ \mathrm{~A} & 38 & 3-5 & 3 & 4.5 & 0.29 & 35 & 29 & 2100 & 950 & 1150 \\ \mathrm{~A} & 24 & 5-6 & 3 & 5.0 & 0.34 & 30 & 25 & 3700 & 2110 & 1300 \\ \mathrm{~A} & 43 & 2-5 & 3 & 4.5 & 0.24 & 43 & 66 & 3000 & 1260 & 3300 \\ & 45 & 0-2 & 4 & 4.7 & 0.28 & 46 & 163 & 5000 & 1330 & 2600 \\ & 38 & 0-2 & 4 & 4.9 & 0.36 & 152 & 38 & 6800 & 2840 & 1050 \\ \mathrm{~K} & 13 & 1-3 & 4 & 4.9 & 0.28 & 65 & 138 & 3900 & 610 & 2220 \\ \mathrm{~K} & 14 & 5-7 & 4 & 5.1 & 0.26 & 53 & 87 & 3400 & 780 & 2010 \\ \mathrm{~K} & 25 & 1-3 & 4 & 4.6 & 0.21 & 65 & 159 & 3400 & 940 & 2380 \\ \mathrm{~K} & 26 & 5-7 & 4 & 4.2 & 0.20 & 58 & 176 & 3500 & 1220 & 3180\end{array}$


Sample Depth Volume Exchange$\begin{array}{llll}\mathrm{dm} & \mathrm{H} & \mathrm{pH} & \text { weight }\end{array}$
Extract- $0.1 \mathrm{~N} \mathrm{Cl-} \mathrm{soluble}$ $\begin{array}{ccc}\text { able } \mathrm{Ca} & & \\ \text { ppm } & \text { Fe ppm } & \text { Al ppm }\end{array}$

\begin{tabular}{|c|c|c|c|c|c|c|c|c|c|c|}
\hline & 103 & $2-4$ & 4 & 4.8 & 0.28 & 130 & 276 & 3200 & 2670 & 1950 \\
\hline & 109 & $1-3$ & 4 & 4.6 & 0.24 & 104 & 120 & 1300 & 2110 & 850 \\
\hline & 111 & $1-3$ & 4 & 4.7 & 0.26 & 61 & 112 & 2400 & 1550 & 2550 \\
\hline $\mathbf{K}$ & 27 & $11-14$ & 4 & 4.4 & 0.23 & 59 & 367 & 2900 & 1670 & 5400 \\
\hline A & 44 & $6-8$ & 4 & 4.3 & 0.27 & 21 & 468 & 3300 & 1670 & 4950 \\
\hline & 110 & $2-4$ & 5 & 4.6 & 0.24 & 45 & 142 & 2800 & 1660 & 2700 \\
\hline B & 15 & $4-6$ & 5 & 4.3 & 0.34 & 11 & 3 & 4600 & 1820 & 750 \\
\hline $\mathbf{K}$ & 36 & $4-6$ & 5 & 4.9 & 0.34 & 72 & 426 & 3700 & 3000 & 5400 \\
\hline A & 17 & $8-10$ & 5 & 4.1 & 0.31 & 27 & 39 & 2000 & 180 & 2500 \\
\hline $\mathbf{K}$ & 30 & $2-5$ & 5 & 4.8 & 0.38 & 70 & 343 & 3600 & 3670 & 3300 \\
\hline \multirow[t]{3}{*}{ K } & 41 & $2-6$ & 5 & 4.2 & 0.28 & 59 & 37 & 3900 & 1280 & 1150 \\
\hline & 23 & $2-4$ & 6 & 5.0 & 0.34 & 141 & 484 & 9800 & 1330 & 4850 \\
\hline & 26 & $2-4$ & 6 & 6.1 & 0.34 & 58 & 20 & 18900 & 280 & 230 \\
\hline $\mathbf{K}$ & 20 & $6-8$ & 6 & 5.4 & 0.30 & 52 & 83 & 3800 & 760 & 2550 \\
\hline & 104 & $2-4$ & 6 & 4.6 & 0.29 & 85 & 135 & 2300 & 2860 & 1750 \\
\hline A & 25 & $8-9$ & 6 & 5.1 & 0.37 & 30 & 240 & 4100 & 2280 & 3400 \\
\hline B & 4 & $8-12$ & 7 & 4.3 & 0.33 & 26 & 309 & 850 & 830 & 5050 \\
\hline B & 16 & $8-12$ & 7 & 4.2 & 0.35 & 11 & 12 & 5000 & 2270 & 1100 \\
\hline B & 12 & $8-12$ & 7 & 4.4 & 0.37 & 15 & 63 & 2400 & 2210 & 1970 \\
\hline B & 11 & $4-6$ & 7 & 4.1 & 0.50 & 23 & 99 & 1570 & 2480 & 2000 \\
\hline A & 21 & $8-10$ & 7 & 5.8 & 0.37 & 20 & 20 & 9000 & 110 & 1550 \\
\hline $\mathbf{K}$ & 19 & $3-5$ & 7 & 5.4 & 0.46 & 59 & 81 & 3400 & 840 & 1680 \\
\hline \multirow[t]{3}{*}{ A } & 50 & $3-5$ & 7 & 4.6 & 0.31 & 39 & 83 & 2100 & 1940 & 1900 \\
\hline & 31 & $3-6$ & 8 & 4.9 & 0.39 & 28 & 105 & 13400 & 800 & 2400 \\
\hline & 30 & $0-3$ & 8 & 4.6 & 0.54 & 44 & 98 & 13200 & 1030 & 2050 \\
\hline A & 9 & $0-3$ & 8 & 4.6 & 0.58 & 62 & 292 & - & 6340 & 2450 \\
\hline \multirow[t]{2}{*}{ A } & 45 & $12-14$ & 8 & 4.9 & 0.52 & 213 & 716 & 2900 & 3390 & 5250 \\
\hline & 32 & $0-5$ & 8 & 4.7 & 0.69 & 40 & 623 & 7700 & 1310 & 6150 \\
\hline \multicolumn{11}{|c|}{ Bryales-Carex peat } \\
\hline $\mathbf{K}$ & 9 & $0-2$ & 1 & 4.9 & 0.16 & 87 & 48 & 5200 & 1330 & 1800 \\
\hline $\mathbf{K}$ & 1 & $0-2$ & 1 & 5.5 & 0.14 & 32 & 0 & 10500 & 110 & 360 \\
\hline \multirow[t]{4}{*}{$\mathbf{K}$} & 10 & $2-3$ & 2 & 5.2 & 0.24 & 44 & 85 & 3700 & 560 & 1650 \\
\hline & 74 & $0-3$ & 2 & 6.2 & 0.20 & 45 & 0 & 13300 & 110 & 70 \\
\hline & 39 & $0-2$ & 2 & 4.7 & 0.23 & 34 & 0 & 4300 & 830 & 540 \\
\hline & 139 & $0-2$ & 2 & 3.9 & 0.48 & 205 & 0 & 4400 & 1400 & 1450 \\
\hline \multirow[t]{8}{*}{$\mathbf{K}$} & 2 & $3-5$ & 3 & 5.2 & 0.28 & 26 & 58 & 8600 & 120 & 2420 \\
\hline & 97 & $0-2$ & 3 & 3.9 & 0.26 & 70 & 0 & 23500 & 720 & 920 \\
\hline & 73 & $0-2$ & 3 & 8.0 & 0.44 & 33 & 219 & 23500 & 330 & 1540 \\
\hline & 75 & $0-2$ & 4 & 5.4 & 0.24 & 70 & 23 & 10200 & 2050 & 1100 \\
\hline & 125 & $4-7$ & 4 & 4.9 & 0.30 & 24 & 19 & 7300 & 2330 & 800 \\
\hline & 134 & $4-10$ & 6 & 5.7 & 0.43 & 51 & 552 & 11500 & 720 & 4950 \\
\hline & 142 & $2-4$ & 5 & 4.8 & 0.53 & 44 & 0 & 11700 & 330 & 120 \\
\hline & 140 & $2-4$ & 6 & 5.1 & 0.58 & 56 & 138 & 14700 & 2560 & 1400 \\
\hline K & 11 & $5-7$ & 7 & 5.0 & 0.37 & 42 & 116 & 4000 & 610 & 2380 \\
\hline $\mathbf{K}$ & 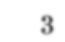 & $7-9$ & 7 & 5.3 & 0.34 & 26 & 68 & 6800 & 450 & 2550 \\
\hline
\end{tabular}

Eutrophic Sphagnum-Carex peat

$\begin{array}{rrrrrrrrrr}91 & 0-2 & 2 & 5.8 & 0.18 & 108 & 0 & - & 0 & 60 \\ 40 & 0-3 & 3 & 5.6 & 0.25 & 54 & 0 & 14000 & 190 & 70 \\ 63 & 3-7 & 5 & 4.7 & 0.32 & 42 & 0 & 9550 & 330 & 480\end{array}$


The analytical results of the peat samples are reported in Table 1. There are 22 samples of Sphagnum peat (Sp), 19 samples of Carex-Sphagnum peat (CSp), 31 samples of Sphagnum-Carex peat (SCp), 43 samples of Carex peat, 16 samples of Bryales-Carex peat $(\mathrm{BC})$, and 3 samples of eutrophic Sphagnum-Carex peat (EuSCp). On account of the low number of samples in some of the peat groups, the samples of Sp and CSp are treated as one group, and so are also the samples of $\mathrm{Cp}, \mathrm{BC}$ and EuSCp.

In order to get a general survey of the material the mean values for the analytical data of each group are calculated. They are recorded in Table 2 which also contains the corresponding standard deviations.

Owing to one sample (number 76) taken from the depth of $60-62 \mathrm{dm}$, the average sampling depth is somewhat higher in the SCp-group than in the other ones. Without sample 76, the mean sampling depth in this group is $3.8 \mathrm{dm}$. Both the average degree of decomposition, $\mathrm{H}$, and the weight of volume appear to be lower in the group of $\mathrm{Sp}$ and $\mathrm{CSp}$ than in the other groups. Also the members of the former group tend to be more acid and contain less samples with a high content of extractable calcium than the other ones do.

Table 2. Mean values of the analytical results in different peat groups

\begin{tabular}{|c|c|c|c|c|c|c|}
\hline $\begin{array}{c}\text { Peat group } \\
\text { Number of samples }\end{array}$ & \multicolumn{2}{|c|}{$\begin{array}{l}\text { Sp and } C S p \\
41\end{array}$} & \multicolumn{2}{|c|}{$\begin{array}{c}\mathrm{SC}_{\mathrm{p}} \\
31\end{array}$} & \multicolumn{2}{|c|}{$\begin{array}{l}\mathrm{C}_{\mathrm{p}} \text { and } \mathrm{BCp} \\
62\end{array}$} \\
\hline & mean & $\mathbf{s}$ & mean & $\mathbf{s}$ & mean & $\mathbf{s}$ \\
\hline Sampling depth, dm & 3.9 & 3.4 & 5.6 & 11.1 & 4.2 & 3.0 \\
\hline $\mathrm{H}$ & 3.1 & 1.9 & 4.0 & 1.6 & 4.6 & 1.9 \\
\hline Weight of volume & 0.24 & 0.12 & 0.32 & 0.09 & 0.32 & 0.11 \\
\hline $\mathrm{pH}$ & 4.3 & 1.8 & 4.5 & 1.8 & 4.9 & 0.6 \\
\hline Extractable $\mathrm{Ca}$, ppm & 3550 & 2000 & 3470 & 2500 & 6200 & 5500 \\
\hline Exchangeables P, ppm & 60 & 34 & 61 & 33 & 56 & 41 \\
\hline $\mathbf{k}$ & 59 & 304 & 101 & 130 & 135 & 165 \\
\hline Acid-soluble Fe, ppm & 880 & 1200 & 1620 & 1490 & 1520 & 1820 \\
\hline $\mathrm{Al}, \mathrm{ppm}$ & 1540 & 1210 & 1900 & 1160 & 2090 & 2220 \\
\hline
\end{tabular}

The data for the nexchangeable» phosphorus are low in all the samples which, of course, is connected with the low content of inorganic phosphorus in Finnish uncultivated peat soils. In a previous work the author (4) found that the average content of inorganic phosphorus in the different peat groups varied from 120 to 180 ppm.

The variation in the values of the coefficient $\mathrm{k}$ seems to be very large. There are numerous samples, particularly in the Sp and $\mathrm{BC}$ proups, which apparently do not retain phosphate under the conditions of the experiment. On the other hand, 
there are samples which have values of $\mathrm{k}$ higher than 300 . For the sake of comparison it may be mentioned that for a clayed and cultivated peat soil which is known to have a high capacity to fix phosphate (according to the method by PIPER (11) its phosphate exchange capacity is about $13000 \mathrm{ppm}$ of $\mathrm{P}$ ) the $\mathrm{k}$ value obtained by the present method was about 300 . The highest $\mathrm{k}$-values of the present material are 623 and 716 for the $\mathrm{Cp}$-samples 32 and $\mathrm{A} 45$, respectively. The average k-values for the different groups are, however, markedly lower: 59, 101, and 135 for the $\mathrm{Sp}$ and $\mathrm{CSp}, \mathrm{SC}$, and $\mathrm{Cp}_{\mathrm{p}}$ and $\mathrm{BC} \mathrm{p}$, respectively. Owing to the large variation, no significant difference exists between the peat groups.

The amounts of iron and aluminum extracted by diluted hydrochloric acid also vary in the present material quite markedly. The lowest iron content is 40 $\mathrm{ppm}$ and the highest one $6340 \mathrm{ppm}$. The corresponding limits for the aluminum content are $70 \mathrm{ppm}$ and $5250 \mathrm{ppm}$, respectively. The average contents of soluble iron and aluminum tend to be lower in the Sp and CSp group than in the other groups, although the differences are not significant. It is of interest to notice that a large part of the samples contains more acid soluble aluminum than acid soluble iron.

In order to study the association between the phosphate retention and the different other factors in these samples, the total correlation coefficients between the values of $\mathrm{k}$ and the sampling depth, the degree of decomposition, the weight of volume, $\mathrm{pH}$, the content of extractable calcium, and the contents of soluble iron and aluminum, respectively, were calculated. The following total correlation coefficients were obtained between $\mathrm{k}$ and

$\begin{array}{lccccccc} & \text { depth } & \mathrm{H} & \mathrm{w} . / \mathrm{v} . & \mathrm{pH} & \mathrm{Ca} & \mathrm{Fe} & \mathrm{Al} \\ \text { Sp and CSp } & -0.01 & 0.24 & 0.33^{*} & 0.07 & -0.19 & 0.49^{* * *} & 0.81^{* * *} \\ \mathrm{SC} \text { P } & 0.15 & 0.16 & -0.10 & -0.17 & -0.25 & 0.75^{* * *} & 0.84^{* * *} \\ \text { Cp and BCp } & 0.35^{* *} & 0.39^{* *} & 0.39^{* *} & 0.01 & 0.06 & 0.30^{* *} & 0.88^{* * *} \\ \text { All samples } & 0.108 & 0.324^{* * *} & 0.319^{* * *} & 0.018 & -0.098 & 0.465^{* * *} & 0.855^{* * *}\end{array}$

The phosphate retention capacity of these peat samples, as characterized by the coefficient $\mathrm{k}$, appears to be most closely connected with the content of acidsoluble aluminum. Also the association with the acid-soluble iron is quite marked, but the extractable calcium or the acidity apparently do not play any important role in the phosphate retention under the conditions of the experiment. There may be some connection with the degree of humification, represented by the $\mathrm{H}$ values and the weights of volume, but the sampling depth is probably only of a minor importance.

The association of the $\mathrm{k}$ values with the amounts of soluble aluminum and iron, and the degree of decomposition $(\mathrm{H})$ was further studied by calculating the partial correlation coefficients in which the effect of each variable was isolated from the effects of the other variables. The elimination of the effect of the soluble iron or the degree of decomposition does not to any noteworthy degree change the correlation between $\mathrm{k}$ and soluble aluminum: the respective partial correlation coefficients are 


$$
\mathrm{r}_{\mathrm{kAl} ; \mathrm{Fe}}=0.838^{* * *} \text { and } \mathrm{r}_{\mathrm{kAl} ; \mathrm{H}}=0.837^{* * *}
$$

The elimination of the effect of soluble aluminum from the correlation between $\mathrm{k}$ and soluble iron decreases the degree of reliability of the association, but the elimination of the effect of the degree of decomposition has less influence. The partial correlation coefficients are

$$
\mathrm{r}_{\mathrm{kFe} ; \mathrm{Al}}=0.362^{* * *} \text { and } \mathrm{r}_{\mathrm{kFe} ; \mathrm{H}}=0.442^{* * *}
$$

The elimination of the effect of soluble aluminum reduces the correlation between $\mathrm{k}$ and the degree of decomposition to a nothingness whereas the elimination of the effect of soluble iron causes a far less decrease:

$$
\mathrm{r}_{\mathrm{kH} ; \mathrm{Al}}=-0.036 \text { and } \mathrm{r}_{\mathrm{kH} ; \mathrm{Fe}}=0.285^{* *}
$$

The partial correlation coefficients between $\mathrm{k}$ and soluble aluminum, or soluble iron, or the degree of decomposition are after the elimination of the effect of the two other variables are the following:

$$
\begin{aligned}
& \mathrm{r}_{\mathrm{kAl} ; \mathrm{FeH}}=0.823^{* * *} \\
& \mathrm{r}_{\mathrm{kFe} ; \mathrm{AlH}}=0.364 * * * \\
& \mathrm{r}_{\mathrm{kH} ; \mathrm{AlFe}}=-0.051
\end{aligned}
$$

Similar results are obtained, if instead of the degree of decomposition the weight of volume is used to indicate the degree of humification.

The multiple correlation coefficient is $\mathrm{r}_{\mathrm{k}(\mathrm{AlFeH})}=0.876^{* * *}$ which proves that the linear regression technique employed is fairly well suited for this material.

The regression equation for estimating $\mathrm{k}(\mathrm{y})$ for any particular values of soluble aluminum $\left(\mathrm{x}_{1}\right)$, soluble iron $\left(\mathrm{x}_{2}\right)$, and $\mathrm{H}\left(\mathrm{x}_{3}\right)$ is thus

$$
\mathrm{y}=0.085^{* * *} \mathrm{x}_{1}+0.022^{* * *} \mathrm{x}_{2}-1.68 \mathrm{x}_{3}-75.2
$$

and the standard deviation of any estimate will be 69.0 .

Owing to the fact that the elimination of the effect of the soluble aluminum content results in the disappearance of the association between $\mathrm{k}$ and the degree of decomposition, $\mathrm{k}$ may be fairly reliably estimated on the basis of the contents of soluble aluminum and iron, only. This regression equation is

$$
\mathrm{y}=0.083^{* * *} \mathrm{x}_{1}+0.021^{* * *} \mathrm{x}_{2}-79.6
$$

and the standard deviation of any estimate will be 68.7. The multiple correlation coefficient is $\mathrm{r}_{\mathrm{k}(\mathrm{AlF})}=0.875^{* * *}$.

\section{Discussion}

As far as the coefficient $\mathrm{k}$ of the present work actually represents the sorption of phosphorus by the peat samples, the results obtained contain some interesting facts. Under the conditions of the experiment the retention of phosphorus varied quite markedly, even within the same kind of peat, and no significant differences 
could be detected between the peat groups, although the Sphagnum peats tended to retain phosphorus to a lower degree than did the fen peats. This sorption was most closely connected with acid-soluble aluminum whereas acid-soluble iron appeared to play a minor role.

The present literature shows an essentially universal agreement that phosphate fixation in acid soils is primarily due to iron and aluminum, but there is very little information as to their mutual importance. Recently Williams et al. (16) found that in mineral soils aluminum extracted by different acid solutions gave highly significant correlations with the phosphate sorption, and in no case did the addition of a term for iron significantly improve the estimate of sorption given by aluminum alone. Although in these peat samples the degree of association of acid-soluble iron with the phosphate sorption was markedly lower than that of acid-soluble aluminum, also the effect of iron had to be counted.

There is, of course, no reason to suppose that just the amounts soluble in diluted hydrochloric acid would be equal to the active fractions of aluminum and iron in peat soils. Williams et al. (16) maintain that aluminum extracted by the Tamm acid-oxalate method is the best single criterion of phosphate sorption in the mineral soils studied. Attention must also be paid to the fact that the peat samples were air-dried and ground which may exert some effect on the retention of phosphate and on the solubility of aluminum and iron.

The results of the present study do not explain the mechanism of the phosphate retention by the peat samples. The Freundlich adsorption isotherm was used, but it does not imply an adsorption process. According to Fisher (3) the equation also applies to many reactions that are not adsorption. It must be emphasized that the values of $\mathrm{k}$ by no means are equal to the phosphate sorption capacity, they only are supposed to be correlated with this quantity the determination of which is difficult, or practically impossible if absolute figures are demanded.

\section{$S u m m$ ary}

The factors on which the retention of phosphorus by peat depends were studied on the basis of a material of 134 virgin peat samples. The coefficient $\mathrm{k}$ in the Freundlich adsorption isotherm $\mathrm{y}=\mathrm{k} \mathrm{c}^{\mathrm{n}}$ was used as an indicator of the phosphate sorption. The association of $\mathrm{k}$ with the sampling depth, the degree of decomposition, weight of volume, $\mathrm{pH}$, extractable calcium, and the iron and aluminum dissolved by $0.1 \mathrm{~N}$ hydrochloric acid was treated.

The acid-soluble aluminum gave with $\mathrm{k}$ a highly significant correlation which did not decrease when the effects of acid-soluble iron and the degree of humification were eliminated. The correlation between $\mathrm{k}$ and the acid-soluble iron was also highly significant although less close than the former association, and it was to some extent lowered by the elimination of the effect of aluminum. The fairly low, although statistically significant correlation between $\mathrm{k}$ and the degree of humification as expressed by the degree of decomposition or by the volume 
weight disappeared when the effect of aluminum was isolated. In the present material the sampling depth, $\mathrm{pH}$ and the content of extractable calcium did not give any significant correlation with $\mathrm{k}$.

As far as these results are valid under natural conditions, aluminum appears to play a more important role in the phosphorus sorption of peat soils than iron does.

\title{
REFERENCES
}

(1) Doughty, J. L. 1930. The fixation of phosphate by a peat soil. Soil Sci. 29: 23-35.

(2) $\longrightarrow$ 1935. Phosphate fixation in soils, particularly as influenced by organic matter. Ibid 40: 191-202.

(3) Fisher, E. A. 1922. The phenomena of absorption in soils: a critical discussion of hypotheses put forward. Trans. Faraday Soc. 17: 305-316.

(4) KaIla, A. 1956. Phosphorus in virgin peat soils. J. Sci. Agr. Soc. Finland 28: 142-167.

(5) KaIlA, A. \& Krvekäs, J. 1957. Extractable calcium, magnesium, potassium and sodium in different peat types. Ibid. 29: 41-55.

(6) Kasakow, E. 1934. Adsorption der Phosphate durch Moorböden. Pedology 29:439 (Ref. Z. Pflanzenern., Düng. Bodenk. 42: 105, 1936).

(7) Kunin, R. 1943. Microdetermination of iron by the mercurous nitrate method. Soil Sci. 55: 457.

(8) Larsen, J. E. 1957. Phosphorus availability in organic soils. Dissert. Abstr. 17: 1880-1881 (Ref. J. Food Agric. 9: i i -92 ).

(9) McCool, M. M. 1921. Peat and muck soils. Fixation of fertilizers. Mich. Quart. Bul. 3: 127.

(10) Olsen, S. R. \& WAtanaBe, F. S. 1957. A method to determine a phosphorus adsorption maximum of soils as measured by the Langmuir isotherm. Soil Sci. Soc. Amer. Proc. 21: 144-149

(11) Piper, C. S. 1944. Soil and plant analysis. New York, 368 p.

(12) Rennie, D. A. \& McKercher, R. B. 1959. Adsorption of phosphorus by four Saskatchewan soils. Canad. J. Soil Sci. 39: 64-75.

(13) Russell, E. J. \& Prescott, J. A. 1916. The reaction between dilute acids and the phosphorus compounds of the soil. J. Agr. Sci. 8: 65-110.

(14) Verhoeven, B. 1946. Fosfaatvastlegging aam indrogende veengronden. Landbowk. Tidschr. 58: $237-242$.

(15) WILD, A. 1950. The retention of phosphate by soil. A review. J. Soil Sci. 1: 227-238.

(16) Williams, E. G. \& Scott, N. M. \& McDonald, M. J. 1958. Soil properties and phosphate sorption. J. Sci. Food Agric. 9: 551-559.

\section{SELOSTUS:}

\section{TURVENÄYTTEIDEN FOSFORIN PIDÄTYKSESTÄ}

\author{
Armi Kaila
}

Yliopiston maanviljelyskemian laitos, Helsinki

Tutkimuksessa on yritetty selvittää turpeiden fosforin pidätyskykyyn vaikuttavia tekijöitä. Aineistona oli 134 luonnontilaisilta soilta kerättyä näytettä, jotka edustivat eri turvelajeja.

Fosforin pidätyskyvyn indikaattorina käytettiin Freundlichin adsorptioyhtälön, $\mathrm{y}=\mathrm{kc}^{\mathrm{n}}$, kerrointa k. Tutkittiin k:n riippuvuutta maatumisasteesta, näytteenottosyvyydestä, tilavuuspainosta, $\mathrm{pH}$ :sta, uuttuvasta kalsiumista sekä $0.1 \mathrm{n}$ suolahappoon liukenevasta raudasta ja aluminiumista. 
Todettiin, että aluminiumin ja k:n välillä vallitsi erittäin voimakas korrelaatio, joka ei heikentynyt, kun raudan tai maatumisasteen vaikutus eliminoitiin. Myös k:n ja raudan välinen korrelaatio oli verraten voimakas, joskin huomattavasti matalampi kuin edellinen. Aluminiumin vaikutuksen eliminointi heikensi jonkin verran k:n ja raudan välistä riippuvuutta ja hävitti kokonaan heikohkon korrelaation k:n ja maatumisasteen văliltä. Näytteenottosyvyys, pH ja kalsiumin pitoisuus eivät tămăn aineiston perusteella vaikuta turpeen fosforin pidätyskykyyn.

Mikäli näitä ilmakuivia näytteitä käyttäen saatuja tuloksia voidaan soveltaa luonnon olosuhteisiin, näyttää aluminium yhdisteineen olevan myös turvemaissa tärkeämpi fosforin pidättäjä kuin rauta. 